\title{
Research Libraries in Latin America
}

\section{Miss Daniels is acting librarian, Pan American Union.}

$\mathrm{F}$

OR MORE THAN IOO years before Har- vard University and its libraries were established, cultural institutions, universities and libraries had flourished in the Spanish and Portuguese colonies of the new world. Together with the early conquistadores came the viceroys, bringing with them collections of legal treatises and the priests with their libraries. It is not strange, therefore, to discover in hundreds of libraries in Latin America today countless volumes of incunabula as well as illuminated manuscripts and thousands of documents of historical importance written by the early colonizers.

The first library collections known to have been set up in the new world were ecclesiastical and viceregal ones. As new universities appeared, libraries were established particularly in the field of law. Private libraries were collected by the wealthy colonizers and treasures were brought from Spain, Portugal, France and Italy. During the eighteenth century many academies and other cultural institutions were established to conform to the same cultural development as in the mother countries, and libraries were formed for the use of their members.

Within a few years-sometimes no longer than months - after their independence was gained, many of the Latin American republics determined to establish national libraries to preserve the documents and books relating to their history and culture. Many of the early ecclesiastical li- braries found their way into the national libraries or into university collections. During the present century government agencies have built up large specialized collections to satisfy their individual needs. In recent years private concerns and international organizations have begun to collect materials of research in the technical and industrial fields which have not generally been the concern of the older scholarly libraries.

Library resources for research purposes in Latin America today are rich indeed in the fields of law, philosophy, literature and the history of the Western Hemisphere. Unfortunately those resources are still largely unexplored because of the meager bibliographical control of many of even the richest collections. A survey of the resources in Latin American libraries would undoubtedly reveal an unimaginable wealth of source material for the scholars of the Americas. Since it would be impossible within a few pages to discuss all research libraries in Latin America, this paper will confine itself to a mere mention of a few of the outstanding libraries important for research purposes. They may be divided into the following general type and will be discussed in that order: national libraries and archives, university, private and institutional, governmental and intergovernmental libraries. A final word will be said about the librarians from the United States who have assisted in the development of libraries in Latin America.

\section{National Libraries}

Despite the disastrous fire of 1943 which bid fair to destroy a magnificent collection 
of books and manuscripts, the National Library of Peru, under the guidance of Jorge Basadre, scholar, historian and librarian, has regained its position as one of the outstanding libraries of the world in the field of the historical research, early geography and travel in the new world as well as one of the best organized libraries in Latin America. Thirty days after Peru proclaimed its independence in $182 \mathrm{I}$, the great liberator José de San Martín decreed the establishment of a National Library and contributed generously from his private collection to the extent that the new library was inaugurated in September of the following year with 11,256 volumes. At the present time the collection has reached a figure of more than 160,000 volumes of which a large portion consists of priceless documents and rare volumes of the early history of the Americas. Among the most valuable collections secured by the National Library of Peru in recent years is the private library of a former president of $\mathrm{Ar}$ gentina, General Agustín P. Justo who had maintained agents throughout the world to locate for him important rare books in the fields of geography and travel, especially of South America.

After the conflagration in 1943 which destroyed thousands of documents, books and pamphlets of great importance, movements to assist in rebuilding the library were organized in various countries of America and Europe, and large national collections were presented to the National Library. A representation from the U.S., consisting of Dr. Luther H. Evans, Ralph Munn and Francisco Aguilera, attended the formal presentation of the gift of several thousand volumes from the "people of the U.S."

The largest and most diversified national library in Latin America is that of Brazil, located in Rio de Janeiro and now compris- ing more than a million printed books and almost as many manuscripts. Its complete resources are still unknown despite efforts during recent years to catalog the collection. The library had its beginnings as the royal private library of King John VI of Portugal. Since the time of the independence of Brazil, many important collections have been added including special ones on natural science, architecture, drawings and prints, German scientific treatises, Jesuits in Paraguay, maps, Portuguese classics, etc. All Brazilian books are required by law to be deposited in the National Library.

The outstanding collection of the $\mathrm{Na}$ tional Library of Chile, located in Santiago, is the "Biblioteca Americana" of more than 30,000 volumes, collected by the renowned bibliographer of the Americas, José Toribio Medina. Included in the collection are the original manuscripts from which Medina reproduced his 500 volume compilation of documents relating to the complete history of Chile. Not only is the collection rich in historical materials pertaining to Latin America, but to the United States as well.

The collection known as the National Library of Mexico, now a part of the Universidad Autónoma of Mexico, is extremely rich in its collection of documents, manuscripts and early books concerning Mexico, Central America and the Spanish Southwest of the United States. In recent years a new library, called the Library of Mexico, has been established to serve the purpose of a national library.

These are but a few of the national libraries of the Latin American nations whose research value is high, especially for the history and development of each country. In reviewing the research facilities of the Latin American nations it is necessary to mention the important role played by the archives in the preservation of historical documents. Two of the richest and best 
organized archival collections are the $\mathrm{Na}$ tional Archives of Guatemala and Cuba. The care and treatment of manuscripts and rare books is so important in most archives, as well as in the national and university libraries in Latin America, that the study of paleography is a required course in most library schools.

The National Museum of Archaeology, History and Ethnography, located in Mexico City, possesses an important library of documents and manuscripts relating to to the Inquisition, the colonization and independence of Mexico, and the colonization of Texas and southwestern United States.

\section{University Libraries}

The Central Library of the University of San Marcos, founded in Lima in the middle years of the sixteenth century, remains today, together with the libraries of the Schools of Law, Medicine and Economics, one of the best research collections in Latin American universities. Of particular importance is the legal collection in the $\mathrm{Li}$ brary of the School of Law.

Among the important university libraries of Latin America one finds the libraries of the University of Buenos Aires, totaling almost a million volumes of books and periodicals. There are six libraries in the schools of law and social sciences, philosophy and medical sciences, exact, physical and natural sciences, economics, and agronomy and veterinary sciences. In order to serve as a bioliographical center for the university and to maintain a union catalog of all its collections, the Instituto Bibliotecológico was established a few years ago. It has a highly selected collection of reference tools and works in library science.

The National Autonomous University of Mexico, in addition to the collection mentioned above as the National Library of Mexico, has more than 20 libraries in its various schools. The libraries of the University of Havana consist of the well organized general library and those of law, engineering and architecture, agronomy, medicine and sciences.

The University of Chile maintains six faculty libraries in addition to the Central Library, where a union catalog of the holdings of all the uinversity libraries is being compiled.

In December 1948, fire almost completely destroyed the School of Medicine of the University of Chile and burned a large portion of the most used collection of its library. However, through the efforts of sympathetic persons in all the Americas, both the library and the laboratory equipment of the school and its affiliated institutes are being rehabilitated.

There is a tendency among Latin American universities today to withdraw their location from the center of the city and to build new "university cities" on the outskirts. Among the universities which have either begun their new buildings or are in the planning stages are Panama, San Marcos, Mexico, Brazil, Colombia and the Central University of Quito. Both the National University of Panama and the Central University of Quito have constructed a new library as one of the first buildings in their new university cities.

Another tendency in university library administration in Latin America is toward a centralization of library services, at least insofar as the maintenance of a union cata$\log$ of the university's library resources is concerned. Librarians from the United States have been asked to assist or to advise in the unification of national university libraries in Mexico, Chile, Panama and the University of San Marcos in Peru. The rectors as well as the librarians of many universities are discussing the advisability of maintaining a central or general library for 
the university, to take the place of or to supplement the existing libraries in the various colleges. Many of the universities are setting up library schools or courses to train not only librarians for their own institutions but for service in other libraries of the nation as well.

\section{Private and Institutional Libraries}

The tradition of private collections placed at the disposal of reputable investigators still persists today in the Latin American nations. One of the most outstanding and famous of such collections is the well organized library of Dr. Jacinto Jijón y Caamaño, of Quito, who has spent a large portion of his life collecting Americana and Ecuatoriana for his library, and art and archaeological treasures for his museum.

In Cuba one of the private libraries of great bibliographical importance to the history of Cuba is that of the lawyer and scholar, Dr. Antonio M. Eligio de la Puente. The Public Library of the Sociedad Económica de Amigos del País, of which Dr. Eligo de la Puente is president, is extremely rich in documents and books as well as newspapers relating to the history of Cuba and the other island possessions of Spain. During the nineteenth and twentieth centuries this library has been the recipient of many large private collections of importance.

One of the most valuable of the private museums and libraries in South America is the Museo Prado in Lima, belonging to the Prado family which has given Peru two of its presidents, Mariano Ignacio Prado of the nineteenth century, and his son the recent president Manuel Prado y Ugarteche. The library is especially rich in the history, literature and social problems of Peru.

Many of the academies of history, language, law, literature, medicine and sciences have maintained large special collections particularly for the use of their members, but frequently open to outside investigators at their request. The Academy of Sciences located in Havana is such an institution.

The Brazilian Historical and Geographical Institute of Rio possesses almost I00,000 volumes in the fields of geography, history and politics. Several important private collections have been presented to the institute in the past few years. Another Brazilian library recently organized but of considerable interest to the students of colonial history is the Imperial Museum located in the former residence of Emperor Peter II of Portugal. Although rich in Brazilian history in general, it is particularly important for its material on the Portuguese empire.

Of recent origin in Latin America is the special library of private concerns or of professional and industrial workers. The Argentine Industrial Union in Buenos Aires maintains a library of more than 15,000 volumes devoted to industrial processes, economics, industry, and industrial and labor law. For the use of its constituents it keeps a file of the laws, decrees and resolutions of the federal and state governments concerning industrial development.

The librarians of 75 technical and scientific institutions in Argentina formed themselves some time ago into the "Comité Argentino de Bibliotecarios de Instituciones Científicas y Técnicas" for the further development of specialized research libraries in the country.

\section{Governmental Libraries}

In addition to the National Libraries of the Latin American nations, many of the ministerial libraries, congressional libraries and other state agencies possess important collections of old and new materials for research. The library of the National Congress in Santiago, Chile, not only preserves 
all legal material necessary for the daily deliberations of congress, but also publishes the bulletin of the sessions of congress and the bulletin of laws and decrees of the government. In Uruguay it is the library of the Legislative Branch of the government which performs the same functions and publishes an index to periodical and newspaper articles of importance.

The Brazilian Institute of Geography and Statistics in Rio maintains an excellent library in its field and issues many geographical and statistical publications. Also in Brazil one finds an outstanding ministerial library, the 30,000-volume collection of the Minister of Labor.

In Haiti a national library plan is currently being drawn up to provide for the formation of large specialized libraries in the various ministries to serve not only the personnel of the ministries but the general public as well. This plan will result in a smaller national library and therefore avoid needless duplication of specialized collections.

Among the principal libraries in Latin America concerning themselves with material for economic research are the federal banks of the various countries, such as those of the Central Bank of the Argentine Republic, the Central Bank of Chile, the Bank of Guatemala and the National Savings Bank of Argentina. The latter publishes a mimeographed bulletin indexing and abstracting important books and periodicals in the field. All these libraries contain current literature in economics, banking, statistics, mathematic and monetary problems, as well as the federal banking laws of other nations.

\section{Intergovernmental Institutions}

One of the oldest and most complete library collections of international governmental institutions is that of the American
International Instituto for the Protection of Childhood, established in Montevideo in 1927. Its 25,000-volume collection covers the fields of child welfare and social science in general. The institute publishes a bibliography concerning child welfare.

Two inter-American organizations affiliated with the Pan American Union in Washington are the Inter-American Institute of Agricultural Sciences in Turrialba, Costa Rica, and the Pan American Institute of History and Geography in Mexico. The library of the former institute provides books and periodical material for research in the field of agricultural economy and experimentation, and shows signs of becoming the leading agricultural library in Latin America. The latter Institute has an outstanding collection of 50,000 historical and geographical books, documents and manuscripts relating to the New World.

\section{Inter-American Library Cooperation}

Many treasures of Latin American libraries have found their diverse ways into the libraries of the United States. One of the richest of these treasures was the library of the former Mexican historian García Icazbalceta, which now forms a part of the collection of the University of Texas. At the same time innumerable librarians from Latin America have come to the United States to study, visit and work in specific libraries so that the knowledge and experience gained here may be applied in their own countries for the development and improvement of their libraries.

Among the institutions which have been instrumental in providing for the movement of librarians between the Americas have been the American Library Association, the Medical Libraries Association, the Department of State, the Pan American Union, the Institute for International Education, the Carnegie Corporation of New 
York, the Rockefeller Foundation and the Library of Congress.

The list of librarians from the United States who have acted as consultants in the reorganization of libraries, or professors in library schools, or directors of libraries and who have thereby contributed to the development of libraries in Latin America is by now an impressive one. Among those who come immediately to mind are: Anita Ker Johinson and Anne Gard who assisted in the National Library of Venezuela; Ione Kidder Maxwell, also of the National Library of Venezuela and the Escuela de Antropología in Mexico (and translator of the L. C. List of subject headings into Spanish); Dorothy Reeder of the National Library in Colombia; R. H. Gjelsness, Sarita Robinson, Janeiro Brooks and Mrs. Clara N. de Villa, professors of library science in Colombia; Raymond Kilgour, Margaret Bates, Josephine Fabilli and Elizabeth Sherier, professors of library science in Peru; Dorcas W. Reid (now Mrs. John M. Connor) teacher of library science in Ecuador, together with the author who also was engaged in library work in Panama and Cuba; Gaston Litton and Virginia Hallam at the University of Panama: Harvie Branscomb, Gaston Litton and William Jackson who surveyed and advised the $\mathrm{Na}$ tional Library of Brazil, and Kathleen Clifford who continued their work; Francis B. Thorne, who taught in northern Brazil; Rodolfo Rivera, who surveyed libraries in
Puerto Rico; Arthur MacAnally who advised the University of San Marcos in Peru; Leslie Dunlap who was loaned briefly to the University of México; Edward Heiliger who served as consultant and professor in the University of Chile; Arthur Gropp who taught library science in Uruguay and his wife Dorothy who pioneered the library field in Brazil; and Ralph Shaw, who recently surveyed scientific libraries in Central America and Mexico. This list does not include the many representatives of the Library of Congress who have visited the libraries of Latin America to improve interlibrary and inter-American relations. It does not include such outstanding directors and personnel of the American libraries in Latin America as Dr. Harry M. Lydenberg, Dr. Richard Bentley, and Bertha Harris, all of the Benjamin Franklin Library in Mexico City. The influence of the American libraries in Mexico, Managua and Montevideo, and the libraries of the American cultural institutes on library development in those countries, cannot be overestimated nor effectively measured.

Comprehensive and authoritative studies of the library resources of the other Americas are urgently needed, not only for the benefit of research workers who may wish to use those resources, but also for a logical planned program of library development in the Latin American nations. The present study can only indicate the vastness of the possibilities of such a survey. 